\title{
Constraints in Pulse Cultivation Perceived by the Farmers of Tal Land in Patna District of Bihar, India
}

\author{
Puja Sinha*, Meera Kumari ${ }^{1}$, Sandeep Kumar ${ }^{1}$ and Ramnath Kumar Ray ${ }^{2}$ \\ ${ }^{1}$ Department of Agricultural Economics, Bihar Agricultural University, Sabour, \\ Bhagalpur-813210, India \\ ${ }^{2}$ Department of Agricultural Economics, BAU, Sabour-813210, India \\ *Corresponding author
}

A B S T R A C T

\section{Keywords}

Pulses, Cropping

Pattern, Tal Area,

Technological \&

Socio-economic,

Constraints

Article Info

Accepted:

22 July 2019

Available Online:

10 August 2019
The study was conducted in two blocks of Patna district of Bihar namely Belchi and Mokama consisting of 60 farmers from each block as sample drawn from six villages i.e. three villages from each block comprises a total of 120 samples of pulse growing farmers . It was observed that major constraints faced by farmers were the non availability of improved variety of seed at time of sowing followed by low profit and lack of proper knowledge of package and practices, insect pest and diseases management etc in almost all selected villages under study.

\section{Introduction}

Pulses in India is considered as poor man's protein. The area under pulses in India was 23 million hectares with an annual production of 15 million tons (2003-04) has been increased to 29.00 million hectare in the year 2017-18 with production of 25.23 million tonnes. However productivity has been increased from $635 \mathrm{Kg} / \mathrm{ha}$ to $841 \mathrm{Kg} / \mathrm{ha}$ over the mentioned period under study (DAC \& FW, GOI 2017-18). The net availability of pulses has came down from $60 \mathrm{gm} /$ day/person in 1951 to $53 \mathrm{gm} /$ day/person (Indian Council of
Medical Research recommends 65 gm/day/capita) in 2017 (DAC \& FW, GOI 2017-18). Therefore there is need to identify the gaps in the present strategy to increase the area under pulses and also to develop the location specific suitable new varieties of seeds to minimises the gap of requirement and availability of pulses in the countries.

In Bihar, pulse crops got major setback as area under pulses has been continuously declining till 2016. Among pulse crop grown in Bihar Lentil is the only pulse crop whose cropped area has been increased by the year 
of 2010, and production is still higher than the national average $(991 \mathrm{~kg} / \mathrm{ha})$. In addition to this, there is a huge variability in area and production of major pulses during 2000-2009, however the productivity during the same period was more stable showed that there is an ample scope to increase the production potential of major pulses in the state if adequate policy measures are taken (Kumari et al 2015/2017). To identify the problem and opportunity, this study has been planned with main aimed to identifying the major constrains faced by the farmers especially in Tal area which is known as bowl of pulse production in Bihar.

\section{Materials and Methods}

The study was conducted in three blocks having highest area under pulses in Patna district of Bihar. Two villages from each block consisting of 20 pulse growers from each village were selected randomly. Thus, the data were collected from 120 farmers through a semi-structured interview schedule by using personal interview technique. Thereafter data were compiled, tabulated, analysed and interpreted as per objectives of the study. Aspect-wise constraints of pulse grower's were worked out. The constraints were categorized into four categories namely infrastructural constraints, socioeconomic constraints, technological constraints and institutional constraints. The frequency of constraints was measured on a three point continuum scale. Weight of 3,2 and 1 were given for most important and least important constraint, respectively. In the next stage rank assigned to each reason by each individual will be converted into per cent position by using the formula

Percent position $=100\left(\mathrm{R}_{\mathrm{ij}}-0.5\right) / \mathrm{N}_{\mathrm{J}}$

Where, $R_{i j}$ stands for rank given for the $I^{\text {th }}$ factor $(i=1,2 \ldots .5)$ by the $j^{\text {th }}$ individual $(j=1$,
$2 \ldots \ldots, n) N_{j}$ stands for number of factors ranked by $\mathrm{j}^{\text {th }}$ individual. After that, the scores for each factor were summed over the number of respondents who ranked that factor. In this way, total scores will be arrived for each of the factors and mean scores will be calculated by dividing the total score by the number of respondents who gave ranks. Final overall ranking of the factors will be carried out by assigning rank 1, 2, 3.. etc., in the descending order of the mean scores.

\section{Results and Discussion}

\section{Descriptive statistics of the sample farmers}

The data on descriptive statistics of sample villages under study in Table 1 indicated that out of 120 respondents only 3 percent of them were educated up to primary level 35 percent of the respondents were undergraduate where as 27.50 percent were having secondary education and 34 percent having higher secondary education. This study also revealed that agriculture constituted the primary occupation of 88 percent of respondents. Size group analysis indicated that 64 percent of the respondents were small farmers having 1- 2 hectares of land followed by marginal (19.17) and Medium farmers (16.67). The percentage area under pulses cultivation was accounted as 40 percent of gross cropped area. Among pulses area under Lentil was accounted 18.38 percent followed by chick pea (11 percent). However area under pigeon pea was only 7 percent of total area under pulse crop was observed during the survey, it may be concluded on the basis of above findings that Rabi pulses was main crop grown by the farmers. Age -wise respondents revealed that about 43 percent of respondent were come under middle age group i.e., 36 to 50 years, only 21 percent comes under young age group i.e., less than 35 year. It may be said that rural youth were not interested in farming which is a need of the hours. 
It may be observed that the relative importance of pulse crop to the total cropped area (Kharif, Rabi and Summer) was accounted nearly about 40 percent in the selected villages under study. Size group analysis revealed that marginal farmers accounted highest percent of area under pulses to the total cropped area accounting 41 percent followed by small farmers (40 percent) and medium farmers in Tal area, due to the fact that pulse crop being less capital intensive may be cultivated extensively to cover all the land under cultivation particularly by the marginal farmers as they do not have other alternative crop to grow in Rabi season.

From the observation of cropping pattern of sample farmers among pulses Rabi pulses were occupied major area followed by the kharif pulse and summer pulse. It may be inferred that district Patna is dominated by crop of lentil and chickpea in Rabi followed by kharif crop (pigeon pea) across each size group of farms. It clearly indicated that pulse crop has been dominating in the cropping pattern of Tal land under study.

\section{Constraints in pulse cultivation}

\section{Socio-economic constraints}

Table 3 revealed the major constraints perceived by the farmers related to their socioeconomic conditions were low profit, high cost of inputs followed by the non availability of credit in time $\&$ high cost of labour.

These were ranked I, II, III \& IV with an overall garret score obtained for same were $69.8,65.4,60.9 \& 44.4$ respectively. The other constraints mentioned under socioeconomic constraints were lack of subsidy for inputs (36.4) and the scarcity of labours (28.3).

\section{Technological constraints}

An analysis of the data under technological constraints is depicted in table 3 indicated that lack of knowledge about seed rate, spacing, sowing date was ranked I on the basis of garret score (66.6) whereas lack of knowledge about insect pest and disease management and lack of knowledge about seed treatment were ranked II and III with an overall score of 62.0 and 54.0 respectively. The other constraints were observed as, lack of knowledge about weed management (38.9) and lack of knowledge about fertilizer dosage and recommended method of its application (29.8).

\section{Institutional constraints}

As far data pertaining to institutional constraints was concerned, it was observed that the linkage between the farmers to research and to the extension personnel was weak and also found that there was no regulated market nearby or even in State as a whole in Bihar where the villagers could sell their produce directly to the consumers. Lack of regulated market was ranked I (57.0), weak research-extension-farmer linkage was ranked II (52.0) and the third in order to this was the non availability of suitable extension material, leaflets etc (41.1) to adopt the better package and practices by the farmers.

\section{Infrastructural constraints}

Infrastructural constraints were categorised as non availability of high yielding varieties (improved variety) of seeds at the time of sowing, non availability of plants protection chemicals. Among these identified constraints, non availability of HYV seeds of pulses and non availability of plant protection chemicals were the two major constraints perceived by the sample farmers as institutional constraints in Tal area that was 
ranked accordingly as I and II having 56.3 garret score followed by the next score of 52.2 in the table 3. However lack of knowledge about the irrigation in pulses due to lack of irrigation facilities was ranked III which was the least important constraint perceived by the sample farmers of both of the block in study area.

In Table 4, The major constraints faced by the sample farmers were summarised into four major constraints as Socio-economic, Technological constraints, Institutional constraints \& infrastructural constraints on basis of mean score of three major constrains of each categories perceived by the farmers respectively. Mean Score obtained from the used technique were found maximum for the socioeconomic constraints followed by technological constraints, institutional constraints and infrastructural constraints ranked as I, II, III \& IV respectively and their garret score was $65.36,60.73,50.00 \& 49.98$ as indicated in table 4. Based on the above findings it may be concluded that there're several constraints faced by the farmers in cultivation of pulses in Tal area of Patna districts of Bihar.

The major constraints identified were non availability of HYV seeds, non availability of plant protection chemicals at the time of sowing, low price of produce, lack of subsidy for inputs, lack of knowledge about seed rate, seed, treatment, weed management dosage and method of application of suitable package and practice available so far area specific technology for pulse cultivation is concerned the similar constraints have also been reported by (Yadav et al., 2002).

Table.1 Social profile of sample farmers

\begin{tabular}{|c|c|c|c|}
\hline S. No. & Parameter & Number & Percentage \\
\hline 1. & Education & & \\
\hline a. & Primary & 4 & 3.33 \\
\hline b. & Secondary & 33 & 27.50 \\
\hline c. & Higher Secondary & 41 & 34.17 \\
\hline d. & Under Graduate & 42 & 35.00 \\
\hline 2. & Land holding & & \\
\hline a. & Marginal (<1.0 ha) & 23 & 19.17 \\
\hline b. & Small (1.0 - $2.0 \mathrm{ha})$ & 77 & 64.17 \\
\hline c. & Medium ( $>2.0$ ha) & 20 & 16.67 \\
\hline 3. & Age group (years) & & \\
\hline a. & $\leq 35$ & 25 & 20.83 \\
\hline b. & $36-50$ & 52 & 43.33 \\
\hline c. & $\geq 50$ & 43 & 35.83 \\
\hline 4. & Occupation & & \\
\hline a. & Agriculture & 105 & 87.50 \\
\hline b. & Subsidiary & 15 & 12.50 \\
\hline 5. & $\begin{array}{l}\text { Area under pulses } \\
\text { cultivation (ha) }\end{array}$ & 1.27 & 39.56 \\
\hline
\end{tabular}

(Source: Compiled by the Authors) 
Table.2 Relative Importance of Pulse crop to total cropped area in study district

\begin{tabular}{|c|c|c|c|c|}
\hline \multicolumn{5}{|c|}{ Cropping pattern } \\
\hline Crop & Marginal & Small & Medium & Overall \\
\hline \multicolumn{5}{|c|}{ kharif } \\
\hline Pigeonpea & $\begin{array}{r}0.06 \\
(3.17)\end{array}$ & $\begin{array}{r}0.14 \\
(5.11)\end{array}$ & $\begin{array}{r}0.46 \\
(7.08)\end{array}$ & $\begin{array}{r}0.18 \\
(5.61)\end{array}$ \\
\hline \multicolumn{5}{|c|}{ Rabi } \\
\hline Lentil & $\begin{array}{r}0.37 \\
(19.58)\end{array}$ & $\begin{array}{r}0.51 \\
(18.61)\end{array}$ & $\begin{array}{r}1.15 \\
(17.69)\end{array}$ & $\begin{array}{r}1.19 \\
(18.38)\end{array}$ \\
\hline Chickpea & $\begin{array}{r}0.26 \\
(13.76)\end{array}$ & $\begin{array}{r}0.33 \\
(12.04)\end{array}$ & $\begin{array}{r}0.51 \\
(7.85)\end{array}$ & $\begin{array}{r}0.7 \\
(10.90)\end{array}$ \\
\hline \multicolumn{5}{|c|}{ Summer } \\
\hline Moong & $\begin{array}{r}0.09 \\
(4.76)\end{array}$ & $\begin{array}{r}0.14 \\
(5.11)\end{array}$ & $\begin{array}{r}0.25 \\
(3.85)\end{array}$ & $\begin{array}{r}0.3 \\
(4.63)\end{array}$ \\
\hline Total & $\begin{array}{r}0.78 \\
(41.27)\end{array}$ & $\begin{array}{r}1.12 \\
(40.88)\end{array}$ & $\begin{array}{r}2.37 \\
(36.46)\end{array}$ & $\begin{array}{r}1.27 \\
(39.56)\end{array}$ \\
\hline $\begin{array}{l}\text { Gross } \\
\text { Cropped } \\
\text { Area }\end{array}$ & $\begin{array}{r}1.89 \\
(100.00)\end{array}$ & $\begin{array}{r}2.74 \\
(100.00)\end{array}$ & $\begin{array}{r}6.50 \\
(100.00)\end{array}$ & $\begin{array}{r}6.46 \\
(100.00)\end{array}$ \\
\hline
\end{tabular}

(Source: Compiled by the Authors)

Table.3 Major constraints in pulse cultivation perceived by the sample farmers

\begin{tabular}{|c|c|c|c|}
\hline S. No. & Constraints & $\begin{array}{l}\text { Garrett } \\
\text { Score }\end{array}$ & Rank \\
\hline 1. & \multicolumn{3}{|l|}{ Socio-economic constraints } \\
\hline a & Low profit. & 69.8 & I \\
\hline $\mathrm{b}$ & High cost of inputs. & 65.4 & II \\
\hline c. & Non availability of credits in time. & 60.9 & III \\
\hline $\mathrm{d}$ & High cost of labour. & 44.4 & IV \\
\hline $\mathrm{e}$ & Lack of subsidy for inputs & 36.4 & $\mathrm{~V}$ \\
\hline $\mathrm{f}$ & Labour scarcity & 28.3 & VI \\
\hline 2. & \multicolumn{3}{|l|}{ Technological Constraints } \\
\hline a. & $\begin{array}{l}\text { Lack of proper knowledge about improved } \\
\text { varieties, seed, rate, spacing and sowing }\end{array}$ & 66.6 & I \\
\hline $\mathrm{b}$ & $\begin{array}{l}\text { Lack of knowledge about insect pest and } \\
\text { diseases management }\end{array}$ & 62.0 & II \\
\hline $\mathrm{c}$ & Lack of knowledge about seed treatment & 53.6 & III \\
\hline $\mathrm{d}$ & Lack of knowledge about weed management & 38.9 & IV \\
\hline $\mathrm{e}$ & $\begin{array}{l}\text { Lack of knowledge about fertilizer dosage and } \\
\text { method of fertilizer application }\end{array}$ & 29.8 & $\mathrm{~V}$ \\
\hline 3. & \multicolumn{3}{|l|}{ Institutional Constraints } \\
\hline $\mathrm{a}$ & Lack of regulated market. & 57.0 & I \\
\hline
\end{tabular}




\begin{tabular}{|c|l|c|c|}
\hline b & Weak research-extension farmer linkages & 51.9 & II \\
\hline c & Non availability of suitable literature. & 41.1 & III \\
\hline 4. & $\begin{array}{l}\text { Infrastructural constraints } \\
\text { a }\end{array}$ & $\begin{array}{l}\text { Non availability of HYV seeds at time of } \\
\text { sowing }\end{array}$ & 56.3 \\
\hline b & $\begin{array}{l}\text { Non availability of plant protection chemicals } \\
\text { in the market }\end{array}$ & 52.2 & II \\
\hline c & Lack of irrigation facilities. & 41.5 & III \\
\hline
\end{tabular}

(Source: Compiled by the Authors)

Table.4 Category wise constraints in pulse cultivation perceived by the sample farmers

\begin{tabular}{|l|l|c|c|}
\hline S. No. & Categories of constraints & Garrett Score & Rank \\
\hline $\mathbf{1}$ & Infrastructural constraints & 49.98 & IV \\
\hline $\mathbf{2}$ & Institutional Constraints & 50.0 & III \\
\hline $\mathbf{3}$ & Technological Constraints & 60.73 & II \\
\hline $\mathbf{4}$ & Socio-economic constraints & 65.36 & I \\
\hline
\end{tabular}

(Source: Compiled by the Authors)

In conclusion, the findings of the present study indicated that heavy losses in production of pulses was due to insect's infestation mainly pod borer, socio-economic constraints, problems of market, lack of improved varieties etc. It provides the feedback to different departments involved in the agriculture development activities, associated universities and various nongovernmental organizations working in agricultural and allied departments to strengthen the research-extension farmer linkage by providing credible input on time to the farmers. There is a need to extend the knowledge regarding plant protection measure and availability of improved seed suitable for Tal area. The technology should be targeted in these areas as cost effective / less costly than the competitive crop so that the farmers could get the net returns equivalent to that they get from the competitive crops they would like to grow. Only then, the farmers will go for cultivation of pulses. To increase area and production of pulses, region specific approaches for package and practices should be adopted in the overall framework of system as well as protection measure need to be developed and distributed to the pulse dominated area.

\section{References}

Chopra K (1982) Pulse production in India- A state wise Analysis, Indian Journal of Agril. Economics37 (3): pp $371-380$.

Kumari M, Meena LK and Bairwa SL (2015) Socio Economic Assessment of Chickpea Growers in Bihar, India. International Journal of Agricultural Science and Research (IJASR) 5 (4): 21-28.

Kumari M. and Bairwa, S.L. (2016) Socioeconomic Assessment of pigeon pea Growers in selected districts of Bihar. The Annals of Agri Bio Research. 21 (1): 101-108.

Kumari M, Singh RG. (2016) Production and Marketing of pulses in Bihar. International Journal of Agricultural Science and Research (IJASR), Vol. 6, Issue 3, Jun 2016, 125-136

Kumari M, and Singh R.G.(2017) Status Problem and Prospects of Chickpea Production in Bihar: A Situation 
Analysis. International Journal of Current Microbiology and Applied Sciences. 6(8): 3555-3563

Kumari M, Bairwa SL, Meena L. and Rahaman M. (2017) Socioeconomic Analysis on Problems and prospects of major pulse productions and consumption in Bihar. International Journal of Current Microbiology and Applied Sciences. 6 (6): 3150-3161.

Success Report on Pulses revolution from food to nutritional security, DES,
Ministry of Agriculture \&FW (DAC\&FW), 2018-19, IVth Advance Estimate.

Ranjan KP and Singh RKP (1998) Cropping Pattern in Backward Agriculture - A Case of North Bihar. Agricultural Situation in India. pp. $69-72$.

Yadav S, Kumar S., Ram J and H, (2002). Sustainable pulse production problems and Prospects. Intensive agriculture, 40: $10-12$.

\section{How to cite this article:}

Puja Sinha, Meera Kumari, Sandeep Kumar and Ramnath Kumar Ray. 2019. Constraints in Pulse Cultivation Perceived by the Farmers of Tal Land in Patna District of Bihar, India. Int.J.Curr.Microbiol.App.Sci. 8(08): 2991-2997. doi: https://doi.org/10.20546/ijcmas.2019.808.346 